\title{
REAKTUALISASI MANAJEMEN KESISWAAN DALAM MEMPERTAHANKAN LOCAL WISDOM (Studi Analisis di MTs Miftahul Ulum Karangmojo, Klego, Boyolali)
}

\author{
Muhammad Miftah \\ STAIN Kudus, Jawa Tengah, Indonesia \\ mubammadmiftah@stainkudus.ac.id
}

\begin{abstract}
This paper discusses how the active role of MTs Miftahul Ulum in maintaining the local culture through structural students' management. Students' management is one of important aspects in educational institutions. It is because base on this, institution can map and plan the future activities in an educational institution. Basically, the students' management discusses the planning of student, students' organization and students' coaching so the students' learning process in educational institutions can be success. Management pattern used in this Madrasa always considers local culture by keeping the culture and customs that exist in the community through its superior programs.
\end{abstract}

Keywords: management, students, strategy, local wisdom. 


\title{
Muhammad Miftah
}

\begin{abstract}
Abstrak
Tulisan ini mengangkat tentang bagaimana peran aktif MTs Miftabul Ulum dalam mempertahankan budaya lokal melalui manajemen kesiswaan yang tersrtuktur, manajemen kesiswaan merupakan salab satu aspek yang penting dalam lembaga pendidikan, karena dari sini lembaga pendidikan dapat memetakan, merencanakan kegiatankegiatan apa saja yang akan dilaksanakan dalam suatu lembaga pendidikan. Pada hakikatnya manajemen kesiswaan membahas mengenai perencanaan kesiswaan, pengorganisasian siswa, pembinaan siswa yang mana semua itu dikemas untuk. kesukesesan dalam suatu proses pembelajaran di lembaga pendidikan. Pola manajemen yang digunakan di Madrasah ini selalu mempertimbangkan budaya lokal yang ada disekitarnya, dengan selalu ikut menjaga budaya dan adat istiadat yang ada di Masyarakat melalui program-program unggulannya.
\end{abstract}

Kata Kunci: manajemen, siswa, strategi, budaya lokal.

\section{A. Pendahuluan}

Keberhasilan dalam suatu kegiatan tidak bisa terlepas dari suatu perencanaan, terlebih dalam dunia pendidikan perencanaan adalah modal pertama dalam kegiatan pembelajaran, sehingga perlu perencanaan yang matang dan strategi yang jitu untuk menghasilkan mutu pendidikan yang memuaskan. Dalam dunia pendidikan banyak komponen-komponen yang mendukung dalam terlaksananya proses pendidikan seperti, sarana dan prasarana, tenaga pendidik, kurikulum, peserta didik serta pembiayaan pendidikan. Komponen-komponen tersebut saling memberikan sumbangan dalam siklus pendidikan.

Berbicara tentang manajemen lembaga pendidikan Islam akan timbul perbincangan tentang sistem pengelolaan lembaga pendidikan "ala" Islam. Hal ini disebabkan lembaga pendidikan Islam mempunyai karakteristik tersendiri sesuai dengan core velue yang dikembangkannya. ${ }^{1}$ Nilai-nilai religi inilah yang selalu

${ }^{1}$ Prim Masrokhan Mutohar, Manajemen Mutu Sekolah Strategi Peningkatan 
dipertahankan dalam pengelolaan lembaga pendidikan Islam. Pola "Islami" dalam manajerial lembaga pendidikan Islam selalu dikedepankan dengan memegang teguh pada ajaran Islam yang bersumber dari al-Quran dan al-Hadis serta keteladanan para alim dan ulama.

Mutu lembaga pendidikan Islam harus menjadi perhatian bersama mengingat lembaga pendidikan Islam di Indonesia akhir-akhir ini selalu tertinggal dengan lembaga pendidikan negeri ataupun lembaga pendidikan swasta lainnya, walaupun penulis mengakui argument ini harus memerlukan data yang lebih valid, akan tetapi kita melihat secara kasap mata, dilihat dari kualitas lembaga pendidikan Islam secara global boleh dikatakan masih "tertinggal" dengan yang lainnya. Ketertinggalan ini bukan karena kuantitas yang dimiliki lembaga pendidikan Islam karena kita melihat secara kuantitas lembaga pendidikan Islam di bandingkan dengan lembaga pendidikan yang lain kita tidak kalah bersaing, yang menjadi persoalan mendasar pengembangan lembaga pendidikan Islam ialah kualitas sumber daya manusia yang dimiliki yang merembet pada kurang profesionalnya sistem pengelolaan lembaga pendidikan Islam.

Dalam upaya peningkatan mutu pendidikan, khususnya pendidikan Islam sangat diperlukan manajemen yang handal untuk dapat mewujudkan cita-cita lembaga pendidikan Agama Islam. Manajemen tersebut akan efektif dan efisien apabila didukung oleh sumber daya manusia yang profesional untuk mengoperasikan dan mengelola kurikulum yang sesuai dengan tingkat perkembangan dan karakteristik siswa, kemampuan dan komitmen tenaga kependidikan yang handal, sarana-prasarana yang memadai untuk mendukung kegiatan belajar mengajar, dana yang cukup untuk menggaji staf sesuai dengan fungsinya, serta partisipasi masyarakat yang tinggi. Bila salah satu hal di atas tidak sesuai dengan yang diharapkan atau tidak berfungsi sebagaimana

Mutu dan Daya Saing Lembaga Pendidikan Islam, (Yogyakarta: Arruz Media, 2013), hlm, 29. 


\section{Muhammad Miftah}

mestinya, maka efektivitas dan efisiensi pengelolaan sekolah Islam tersebut kurang optimal.

Respon aktif lembaga pendidikan Islam dalam mengoptimalkan sistem manajerial madrasah harus didukung dari berbagai elemen, yang pada akhirnya bentuk-bentuk respon inilah menjadi sebuah siklus sistem dalam pengelolaan lembaga pendididikan yang berbasis Islam. Dengan adanya sistem yang sudah terstruktur dengan baik pola manajerial akan berjalan sesuai dengan rencana yang sudah disepakati.

Sementara itu salah satu elemen keberhasilan pendidikan Islam ialah peserta didik atau boleh dikatakan sebagai siswa. Siswa merupakan input dalam suatu lembaga pendidikan. Sedangkan keberhasilan suatu pendidikan dapat dilihat atau dipandang melalui output yang dihasilkan. Output yang mempunyai mutu atau kualitas yang tinggi tidak mungkin kalau dihasilkan dengan input yang rendah. Output yang tinggi biasanya dihasilkan melalui input yang tinggi pula. Maka dari itu suatu sekolah Islam yang ingin meningkatkan kualitas pendidikannya harus meningkatkan kualitas inputnya.

Memang tidak semua orang sepakat ukuran dari kesuksesan dari suatu lembaga pendidikan itu diukur dengan input peserta didik yang bagus. Banyak sekali sekolah-sekolah yang inputnya baik tapi kenyataannya outputnya kurang berhasil atau kurang bermutu. Ketika diselidiki, hal itu bukan disebabkan pendidikan atau materinya akan tetapi disebabkan manajemen kesiswaannya yang kurang baik.

\section{B. Pembahasan}

\section{Manajemen Kesiswaan}

Berdasarkan asal kata, pengertian manajemen kesiswaan merupakan penggabungan dari kata manajemen dan kesiswaan. Manajemen sendiri dartikan bermacam-macam. Secara etimologis, kata manajemen merupakan terjemahan dari management yang 
berasal dari bahasa Inggris. Kata ini berasal dari bahasa Latin, Prancis dan Italia yaitu manus, mano, manage dan maneggiare. maneggiare berarti melatih kuda agar dapat melangkah dan menari seperti yang dikehendaki pelatihnya. Istilah manajemen berasal dari kata kerja to manage yang berarti control. Dalam bahasa Indonesia dapat diartikan: mengendalikan, menangani atau mengelola. Hal ini senada dengan yang diungkapkan Yayat M. Herujito dalam bukunya yang berjudul "Dasar-dasar Manajemen" menyatakan bahwa manajemen adalah pengelolaan, pengendalian atau penanganan suatu hal dalam mencapai suatu tujuan tertentu. ${ }^{2}$

Manajemen dapat juga dipandang juga sebagai seni untuk melakukan pekerjaan melalui orang lain, dengan kata lain The art of getting things done through the people. ${ }^{3}$ Pengertian ini bermakna seorang pemimpin (manajer) harus mempunyai keahlian lebih dalam mengelola lembaga yang dipimpinnya, selain itu manajemen yang setangguh apapun masih tetap memerlukan peran orang lain. Walhasil seorang manajer tidak hanya sebatas sebagai sebuah profesi akan tetapi manajer harus mempunyai gaya kepemimpinan yang bisa mengelola lembaga dalam situasi dan kondisi apapun agar tetap kondusif dan dapat dikendalikan.

Sedangkan kata kesiswaan mempunyai banyak sekali sebutan diantaranya: pembelajar, murid, santri, peserta didik. Peserta didik sendiri menurut ketentuan umum Undang-undang RI No. 20 tahun 2003 tentang Sistem Pendidikan Nasional adalah anggota masyarakat yang berusaha mengembangkan potensi diri melalui proses pembelajaran yang tersedia pada jalur, jenjang, dan jenis pendidikan tertentu. ${ }^{4}$ hlm. 1.

${ }^{2}$ Yayat M Herujito, Dasar-dasar Manajemen,(Jakarta: Grasindo, 2001),

${ }^{3}$ Stoner (1986), dalam Prim Masrokhan Mutohar, Manajemen Mutu Sek lah Strategi Peningkatan Mutu dan Daya Saing Lembaga Pendidikan Islam, (Yogyakarta: Arruz Media, 2013), hlm, 32.

4 Undang-undang RI No. 20 tahun 2003 tentang Sistem Pendidikan Na sional. 


\section{Muhammad Miftah}

Dari pengertian di atas dapat disimpulkan bahwa yang dinamakan siswa adalah sekelompok orang atau individu yang mengembangkan potensi yang dimilikinya dan mendapatkan pelayanan sesuai dengan bakat dan minat serta kemampuannya agar dapat tumbuh secara optimal. Maka dari itu manajemen kesiswaan dapat didefinisikan sebagai kegiatan pencatatan siswa mulai dari proses penerimaan hingga siswa tersebut lulus dari sekolah dikarenakan tamat atau sebab yang lain. Tidak semua hal yang berhubungan dengan siswa termasuk dalam manajemen siswa, tetapi adakalanya termasuk dalam manajemen yang lain. ${ }^{5}$

Berbeda dengan yang diungkapkan Suharsimi Arikunto, manajemen siswa bukan hanya bebentuk pencatatan peserta didik, melainkan meliputi aspek yang lebih luas yang secara operasional dapat membantu upaya pertumbuhan dan perkembangan peserta didik melalui proses pendidikan disekolah. ${ }^{6}$ Dari situ memberikan gambaran bahwa manajemen kesiswaan bukan hanya sekadar pencatatan-pencatatan semata, namun meliputi segala aspek yang berkaitan dengan aktifitas siswa mulai dari perencanaan sampai dengan evaluasi.

Manajemen kesiswaan atau bisa disebut juga dengan pupil personal administration merupakan sebuah usaha pengelolaan atau pengaturan terhadap peserta didik mulai dari siswa masuk ke sekolah hingga peserta didik dinyatakan lulus. ${ }^{7}$ Definisi ini memang masih perlu dikritisi karena manajemen kesiswaan sebelum siswa mendaftarkan diri masuk ke sekolah manajemen kesiswaan itupun sudah dimulai walaupun dalam bentuk-bentuk manajemen dan tata kelola yang tidak bisa dilihat dengan kasap mata.

Dengan demikian dapat ditarik kesimpulan bahwa manajemen kesiswaan merupakan suatu penataan atau pengaturan

${ }^{5}$ Suharsimi Arikunto, Lia Yuliana, Manajemen Pendidikan, Yogyakarta: Aditya Media, 2008), hlm. 57.

${ }^{6}$ Abdul Rahman Saleh, Madrasah dan Pendidikan Anak Bangsa Visi Misi dan Aksi,(Jakarta: Raja Grafindo Persada, 2001), hlm, 231

${ }^{7}$ Ali imron, Manajemen Peserta Didik Berbasis Sekolah, Jakarta: Bumi A sara, 2011), hlm. 6. 
segala aktifitas yang berkaitan dengan siswa, yaitu mulai dari masuknya siswa sampai dengan keluarnya siswa tersebut dari suatu sekolah atau suatu lembaga. ${ }^{8}$ Jadi manajemen kesiswaan dapat diartikan sebagai usaha pengaturan terhadap peserta didik mulai dari peserta didik memilih sekolah mana yang akan dipilih, hingga masuk sekolah sampai dengan mereka lulus sekolah. Yang diatur secara langsung adalah segi-segi yang berkenaan dengan peserta didik secara langsung seperti kegiatan-kegiatan dilaksanakan oleh siswa, dan segi-segi lain yang berkaitan dengan peserta didik secara tidak langsung seperti pencatatan siswa yang dilakukan petugas adminitrasi sekolah.

\section{Ruang Lingkup Manajemen Kesiswaan}

a. Penerimaan Siswa Baru

Proses penerimaan siswa baru boleh dikatakan titik mula dalam siklus pembelajaran, karena dari sini sangat menentukan dalam proses pembelajaran baik dari segi pendanaan, manajemen kelas dan rencana kegiatan yang akan dilaksanakan. Maka dari situ perlu strategi khusus dalam penerimaan siswa baru, agar rencana yang sudah dirancang dapat berjalan sesuai dengan yang diharapkan.

Dalam hal penerimaan siswa baru ada beberapa tehnik agar perekrutan siswa baru dapat berjalan dengan baik. Hal-hal yang perlu ditempuh dalam penerimaan siswa baru diantaranya:

1) Pendekatan formal

Pendekatan ini dilakukan untuk mempromosikan sekolah, agar masyarakat dan khalayak umum mengerti bahwa sekolahan sedang membuka pendaftaran siswa baru dengan cara menyebarkan brosur, memasang spanduk dan baliho, serta mempublikasikan diberbagai media cetak maupun elektronik. ${ }^{9}$

${ }^{8}$ Hasbullah, Dasar-dasar Ilmu Pendidikan, (Jakarta: Raja Grafindo Pe sada, 2005), hlm. 87.

${ }^{9}$ Mujamil Qomar, Manajemen Pendidikan Islam, (Jakarta: Erlangga, 2007), hlm. 144. 


\section{Muhammad Miftah}

Pendekatan ini juga dilakukan MTs Miftahuhul Ulum dengan menyebar spanduk dan pengumuman di sekolah tingkat dasar yang ada disekitar wilayah madrasah, seperti yang diutarakan pihak madrasah bahwa penyebaran brosur dan pengumuman dilakukan agar masyarakat mengerti bahwa MTs Miftahul Ulum masih menerima pendaftaran siswa baru. Madrasah Miftahul Ulum dalam mempromosikan sekolahnya tidak hanya lewat media cetak namun juga mempromosikan lewat elektronik yaitu dengan radio komunitas yang ada di wilayah tersebut dan media online, yang mana lebih efektif dalam mempublikasikan madrasahnya di mata masyarakat.

Strategi seperti ini jika dilihat dari perspektif ekonomi memang terlalu besar biaya yang dikeluarkan, akan tetapi tingkat efektifitasnya lebih tinggi karena menyasar langsung pada objek tujuan dari pemasaran yang diharapkan. Pola dalam mengembangkan strategi ini dilakukan dengan tehnik pemetaan di awal, sebagai perencanaan lokus mana saja yang akan dibidik sebagai tujuan dari pemasaran madrasah melalui media cetak maupun media elektronik.

2) Pendekatan Sosial Keagamaan

Pendekatan ini diwujudkan dengan rasa kepedulian sosial seperti pemberian santunan kepada anak yatim, pemberian bantuan kepada masyarakat yang kurang mampu, mengadakan kegiatan sosial pada saat hari-hari besar keagamaan. Setiap hari raya Idul Adha, MTs Miftahul Ulum selalu mengadakan kegiatan tahunan yaitu penyembelihan hewan qurban dan selalu melibatkan masyarakat sekitar dalam kegiatan itu, sehingga hubungan masyarakat sekitar dengan madrasah terjalin dengan baik. Tidak cukup dengan seperti itu dalam perayaan hari besar keagamaan lainnya, Madrasah selalu mengadakan perayaan yang berkoordinasi dengan tokoh masyarakat dan pemuda yang ada disekitar masyarakat. 


\section{3) Pendekatan Kultural}

Pendekatan kultural dilakukan dengan cara menyesuaikan kultur masyarakat yang ada di sekitar sekolahan, pendekatan semacam ini dilakukan agar masyarakat lebih akrab dan dekat dengan sekolah. Mayoritas masyarakat yang berada di daerah madrasah merupakan warga Nahdliyin, yang selalu mempertahankan budaya keislaman dan adat istiadat masyarakat. Tehnik yang ini dilakukan agar animo masyarakat kepada madrasah semakin tinggi, dengan selalu berperan aktif dalam acara adat yang diselenggarakan masyarakat, seperti acara sedekah bumi, bersih desa dan yang lainnya.

Pendekatan seperti ini selain bertujuan untuk mencari perhatian dari masyarakat juga untuk mewujudkan Visi dan Misi Madrasah ini sendiri, yang secara tidak langsung memiliki cita-cita seperti maqalah "Almukhafadhatu 'ala qadimissalib walabdu bil jadidil aslab" yaitu mencoba menjaga tradisi dan budaya para leluhur dan ikut berpartisipasi dalam membuat dan mengemas budaya baru atau adat baru yang memberikan dampak positif bagi masyarakat umum.

4) Pendekatan Rasional dan Profesional

Pendekatan ini dilakukan dengan cara menunjukan keunggulan-keunggulan madrasahnya dibandingkan dengan madrasah lainnya, dengan menunjukan prestasi-prestasi yang sudah diraih dari para siswa maupun guru yang ada. Tidak hanya sebatas itu, keunggulan tidak hanya sebatas pada prestasi yang sudah diraihnya, akan tetapi juga dalam kelengkapan sarana dan prasarana yang dimiliki termasuk letak geografis madrasah yang sangat mudah dijangkau dengan moda transportasi yang ada.

5) Pembinaan Terhadap Sekolah

Pembinaan dilakukan kepada sekolah-sekolah yang menjadi basis calon peserta didik, selain itu juga ikut membantu dalam kegiatan ekstrakulikuler yang diadakan sekolahan tersebut, seperti halnya yang dilakukan MTs Miftahul Ulum selalu ikut 


\section{Muhammad Miftah}

berperan aktif dalam membantu kegiatan kepramukaan di madrasah ataupun sekolah-sekolah tingkat dasar yang ada di sekitarnya.

b. Pembinaan dan Pengembangan Kesiswaan

1) Jenis-jenis Pembinaan Kesiswaan

Dalam PP No. 28 tahun 1990 tentang pendidikan dasar dan PP No. 29 tahun 1990 tentang pendidikan menengah digunakan istilah bimbingan. Pengertian bimbingan menurut PP No. 29 tahun 1990 Bab x pasal 27, yaitu bantuan yang diberikan kepada siswa dalam rangka upaya menemukan pribadi, mengenal lingkungan, dan merencanakan masa depan. Bimbingan diberikan oleh guru pembimbing. ${ }^{10}$

Menurut Hendiyat Soetopo bimbingan adalah proses bantuan yang diberikan kepada siswa dengan memperhatikan kemungkian dan kenyataan tentang adanya kenyataan tentang adanya kesulitan yang dihadapi dalam rangka perkembangan yang optimal, sehingga mereka memahami dan mengarahkan diri serta bertindak dan bersikap sesuai tuntutan situasi lingkugan sekolah, keluarga dan masyarakat. ${ }^{11}$

Bagaimanapun, pembinaan kesiswaan sebagai bagian dari pelaksanaan manajemen kesiswaan berkaitan dengan menyiapkan mutu kelulusan yang berkualitas di setiap sekolah. ${ }^{12}$ Setelah siswa diterima sebagai dari bagian dari warga yang belajar, maka secara praktis siswa mempunyai hak dan kewajiban yang sama dalam suatu lembaga pendidikan, maka sekolah harus selalu memantau segala aktifitas siswa, hal ini dimaksudkan agar dapat mengetahui perkembangan siswa.

${ }^{10}$ Tim Dosen Adminitrasi pendidikan UPI, Manajemen Pendidikan, (Ban ung: Alfabeta, 2009), hlm. 215.

${ }_{11}$ Hendayat Soetopo, Pengantar Operasional Administrasi Pendidikan, (J karta: Raja Grafindo, 2002), hlm. 46.

${ }^{12}$ Syafarudin, Manajemen Lembaga Pendidikan Islam, (Jakarta: Ciputat Pres, 2005), hlm. 266. 
Tujuan melakukan pemantauan meliputi pengawasan terhadap kinerja individual dan perkembangan dalam wilayah akademik, kemampuan kelompok, dan perilaku siswa secara personal. ${ }^{13}$ Pembinaan peserta didik dapat dilakukan dengan mengadakan program-program ekstrakulikuler dan program pembinaan kedisiplinan diantaranya:

a) Orientasi Siswa

Kegiatan orientasi peserta didik (siswa baru) adalah kegiatan penerimaan siswa baru dengan mengenalkan situasi dan kondisi lembaga pendidikan madrasah tempat dimana peserta didik itu akan menempuh pendidikan. Situasi dan kondisi ini menyangkut lingkungan fisik sekolah dan lingkungan sosial sekolah. ${ }^{14}$ Dalam perkembanganya banyak sekali istilah yang muncul dalam kegiatan orientasi siswa ini. Ada yang menamakan kegiatan ini dengan MOS (Masa Orientasi Siswa), POS (Pekan Orientasi Siswa, dan ada juga yang menyebutnya dengan MOPD (Masa Orientasi Peserta Didik), adapun dari beberapa nama tersebut semuanya bertujuan untuk mengenalkan lingkungan sekolah.

Tujuan diadakannya kegiatan orientasi siswa dalam suatu lembaga pendidikan antara lain:

1) Agar para siswa siap untuk menghadapi lingkungan belajar yang baru, baik secara mental atau fisik dan emosional sehingga para siswa nyaman dalam proses pembelajaran.

2) Ditujukan agar para siswa baru, mengerti mentaati segala peraturan-peraturan yang ada di sekolah dan dapat berperan aktif dalam kegiatan-kegiatan yang diselenggarakan sekolah.

${ }^{13}$ Carolyn M Everton Dan Edmund T. Emmer, Manajemen Kelas Untuk Guru sekolah Dasar, (Jakarta: Kencana, 2001), hlm. 182.

14 Tim Dosen Adminitrasi pendidikan UPI, Manajemen Pendidikan.... hlm. 210 . 


\section{Muhammad Miftah}

b) OSIS (Organisasi Siswa Intra Sekolah)

OSIS merupakan salah satu kegiatan diluar kurikuler, dan dalam pelaksanaanya diserahkan kepada para siswa. Keberadaan OSIS merupakan wahana sekaligus wadah bagi siswa untuk menyalurkan bakat dan kreativitasnya sesuai dengan apa yang diinginkan.

Dalam pelaksanaannya kepala madrasah atau para guru harus melakukan beberapa langkah agar kegiatan OSIS ini dapat berjalan dengan baik dan lancar diantaranya:

1) Memberikan kepercayaan dan kewenangan yang sepenuhnya kepada siswa untuk mengelola kegiatanya.

2) Menjalin kerjasama dengan berbagai unit kegiatan remaja diluar sekolah, seperti: Palang Merah Remaja, Kwartir Pramuka, Remaja Masjid.

3) Mengkoordinasikan berbagai kegiatan dengan guru mata pelajaran dan wali kelas. Hal itu dimaksudkan agar jangan terjadi tumpang tindih kegiatan yang mengganggu kegiatan pembelajaran di kelas.

1) Fungsi Pembinaan Kesiswaan

a) Fungsi Pengadaptasian

Membantu guru atau guru atau tenaga edukatif lainnya untuk menyesuaikan program pengajaran yang disesuaikan, dengan minat, kemampuan, dan cita-cita peserta didik.

Pembinaan seperti ini lebih menekankan pengembangan minat dan bakat yang dimiliki peserta didik sejak dini. Sehingga bakat yang dimiliki peserta didik tidak mandeg namun bakat itu akan berkembang secara maksimal.

b) Fungsi Penyesuaian

Membantu peserta didik dalam menyesuaikan diri dengan bakat, minat, dan kemampuanya untuk mencapainya, dengan 
cara mengarahkan dan membimbing peserta didik sesuai dengan bakat yang dimiliki.

c) Fungsi Penyaluran

Membantu peserta didik dalam memilih jenis sekolah lanjutannya, memilih lapangan pekerjaan sesuai dengan bakat, minat, kemampuan dan cita-citanya.

c. Kelulusan dan Alumni

Kegiatan yang paling ujung dalam proses manajemen kesiswaan adalah kelulusan. Kelulusan adalah pernyataan dari lembaga pendidikan bahwa yang bersangkutan sudah memenuhi segala syarat kelulusan dan sudah selesai dalam melaksanakan semua program yang telah diadakan suatu lembaga pendidikan.

Secara formal ketika siswa sudah dinyatakan lulus maka secara otomatis hubungan siswa dengan lembaga pendidikan sudah selesai. Akan tetapi, hubungan antara alumni dengan lembaga pendidikan diharapkan tetap terjalin, karena dengan hubungan yang terjalin ini sekolah dapat menggali informasi tentang lapangan pekerjaan, dan materi-materi pelajaran yang menunjang untuk studi ketingkat selanjutnya.

Banyak sekali cara untuk mempererat hubungan sekolah dengan alumni, diantaranya membuat ikatan alumni per periode, melakukan pertemuan alumni tahunan (reuni). Dari kegiatankegiatan tersebut maka pihak sekolah dapat mendata para alumni yang berprestasi, dan catatan ini dapat dijadikan sebagai daya tarik tersendiri dalam mempromosikan lembaga pendidikannya.

\section{Prinsip-prinsip Manajemen Kesiswaan}

Agar tujuan dan fungsi manajemen kesiswaan dapat tercapai, ada beberapa prinsip yang perlu diperhatikan dalam pelaksaannya. Prinsip-prinsip yang dimaksud adalah sebagai berikut: 
a. Dalam pengembangan progam manajemen kesiswaan, penyelenggara harus mengacu pada peraturan yang berlaku pada saat progam dilaksanakan.

b. Manajemen kesiswaan dipandang sebagai bagian keseluruhan manajemen sekolah. Oleh karena itu, ia harus mempunyai tujuan yang sama dan mendukung terhadap tujuan manajemen sekolah secara keseluruhan.

c. Segala bentuk kegiatan manajemen kesiswaan haruslah mengemban misi pendidikan dan dalam rangka mendidik siswa.

d. Kegiatan-kegiatan manajemen kesiswaan haruslah diupayakan untuk mempersatukan siswa yang mempunyai keragaman latar belakang dan punya banyak perbedaan. Perbedaan-perbedaan yang ada pada siswa tidak diarahkan bagi munculnya konflik diantara mereka melainkan justru untuk mempersatukan, saling memahami dan saling menghargai. Sehingga setiap siswa memiliki wahana untuk berkembang secara optimal.

e. Kegiatan manajemen kesiswaan haruslah dipandang sebagai pengaturan terhadap pembimbingan siswa.

f. Kegiatan manajemen kesiswaan haruslah dipandang mendorong dan memacu kemandirian siswa. Prinsip kemandirian akan bermanfaat tidak hanya ketika di sekolah, melainkan juga ketika sudah terjun ke masyarakat.

g. Kegiatan manajemen kesiswaan haruslah fungsional bagi kehidupan siswa, baik di sekolah lebih-lebih di masa depan.

\section{Fungsi Manajemen Kesiswaan}

Fungsi manajemen kesiswaan adalah sebagai wahana bagi siswa untuk mengembangkan diri se-optimal mungkin, baik yang 
berkenaan dengan segi-segi individualitasnya, segi sosial, aspirasi, kebutuhan dan segi-segi potensi siswa lainnya.

Sedangkan tujuan manajemen kesiswaan adalah manata proses kesiswaan mulai dari perekrutan, mengikuti pembelajaran sampai dengan lulus sesuai dengan tujuan institusional agar dapat berlangsung secara efektif dan efisien. ${ }^{15}$ Maka dari itu tujuan manajemen kesiswaan adalah mengatur kegiatan-kegiatan siswa agar kegiatan-kegiatan tersebut dapat menunjang proses pembelajaran di lembaga pendidikan (sekolah); lebih lanjut, proses pembelajaran di lembaga tersebut (sekolah) dapat berjalan lancar, tertib dan teratur sehingga dapat memberikan kontribusi bagi pencapaian tujuan sekolah dan tujuan pendidikan secara keseluruhan.

\section{Problematika Manajemen Kesiswaan Dalam Memper- tahankan Local Wisdom}

a. Dalam Bidang Penerimaan Siswa Baru

Persaingan antara sekolah satu dengan yang lainnya dalam dunia pendidikan, dalam hal penerimaan siswa baru sangatlah ketat. Begitu juga yang terjadi di MTs Miftahul Ulum, yang mana jarak antar sekolahan SMPN dan MTs N sangatlah dekat sehingga antusias calon peserta didik kebanyakan memilih untuk mendafatarkan ke sekolah Negeri.

Dengan begitu praktis peminat peserta didik memilih untuk sekolah negeri sebagai opsi yang pertama dan menjadikan MTs Miftahul Ulum sebagai alternatif yang terakhir, dengan cara strategi jemput bola \& reward, selain datang langsung ke sekolahsekolah yang menjadi basis dari calon peserta didik, MTs Miftahul Ulum juga memberikan reward (hadiah atau pengahargaan) bagi lima puluh siswa yang mendaftarkan diri pertama kali.

Siswa yang diterima berasal dari berbagai lapisan masyarakat yang bersifat heterogen yang memiliki latar belakang pendidikan

15- Rohiat, Manajemen Sekolab Teori Dasar dan Praktik, (Bandung: Rafika Aditama, 2010), hal. 25. 


\section{Muhammad Miftah}

yang berbeda, sosial keagamaan dan pemahaman keagamaan yang berbeda-beda. Hal inilah yang menjadi batu sandungan pengelola dalam mengembangkan manajemen pendidikan berbasis budaya lokal. Salah satu strategi yang dilakukan untuk meminimalisir hal ini yaitu dengan menyisipkan budaya lokal dalam setiap agenda kegiatan yang diadakan MTs Miftahul Ulum.

b. Dalam Bidang Pembinaan Kesiswaan

Pembinaan kesiswaan yang ada MTs Miftahul Ulum walaupun sudah berjalan, namun kebaradaannya belum begitu banyak memberi manfaat yang berarti bagi siswa khususnya, dikarenakan para pembimbing yang ada, tidak ada yang mempunyai kompetensi di bidang psikologi, walhasil dalam pelaksanaannyapun terkesan hanya sebagai tempat untuk memberi sanksi bagi siswa yang melanggar peraturan. Untuk mengatasi hal ini sebenarnnya MTs Miftahul Ulum menyiasatinya dengan mencari tenaga ahli dibidang itu, namun sampai saat ini belum juga mendapatkannya. Minimnya SDM yang dimiliki menjadikan pembinaan kesiswaan sedikit terbengkalai, pembinaan kesiswaan inilah salah satu upaya yang dilakukan M'Ts Miftahul Ulum dalam mengenbangkan manajemen kesiswaan dalam rangka mempertahankan budaya lokal yang ada di masyarakat.

c. Dalam Bidang Output (Alumni)

Madrasah kesulitan untuk menjalin komunikasi dengan para alumni, karena sebagian besar alumni yang ada merantau ke luar kota. Walaupun setiap tahunnya selalu diadakan reuni namun prosentase alumni yang hadir tidaka sampai 50\%. Dalam rangka mempererat komunikasi antar alumni fihak sekolah membuat komunitas alumni per-periode, dengan memanfaatkan jejaring sosial, strategi ini dilihat lebih efektif dibanding dengan reuni yang diadakan setiap tahunnya. Jejaring alumni inilah dijadikan salah satu upaya yang dilakukan Manajemen MTs Miftahul Ulum dalam melestarikan budaya lokal yang ada di lingkungan masyarakat, dengan cara mengadakan agenda-agenda kegiatan yang bersifat 
rutin setiap tahun. Kegiatan ini dirancang untuk mempertahankan budaya lokal yang berkembang di masyarakat sekitar dengan menjalin kerja saa dengan para alumni yang tersebar di kota besar, salah satu kegiatan yang sering dilakukan ialah acara Nyadran, Dekah deso, dan perayaan hari besar keagamaan.

\section{Simpulan}

Manajemen kesiswaan adalah salah satu aspek yang penting dalam lembaga pendidikan, karena dari sini lembaga pendidikan dapat memetakan, merencanakan kegiatan-kegiatan apa saja yang akan dilaksanakan dalam suatu lembaga pendidikan. Pada hakikatnya manajemen kesiswaan membahas mengenai perencanaan kesiswaan, pengorganisasian siswa, pembinaan siswa yang mana semua itu dikemas untuk kesuksesan dalam suatu proses pembelajaran di lembaga pendidikan.

Di katakan sekolah itu bermutu jika sekolah itu dapat mengakomodir segala hal-hal yang dibutuhkan peserta didik dalam proses pembelajaran dan menyediakan pelayanan yang memadai bagi siswa baik dari sisi kuantitas maupun kualitasnya, sehingga kegiatan dalam proses pembelajaran dapat berjalan dengan lancar dan normal seperti yang diharapkan.

Keberadaan manajemen kesiswaan dalam lembaga pendidikan berfungsi sebagai pengatur serta menjadi penggerak roda pendidikan itu sendiri, sekolah dan masyarakat tidak bisa di pisahkan keduanya saling memberikan warna tersendiri dalam harmoni kehidupan, maka dari itu manajemen kesiswaan di kemas sedemikian rupa agar tetap dapat "bertegur sapa" dengan budaya lokal masyarakat setempat. Dengan mendesain secara langsung aspek-aspek yang berkaitan dengan siswa diantaranya: Perencanaan kesiswaan, penerimaan siswa baru, pengorganisasian siswa, bimbingan kesiswaan bahkan sampai siswa itu sudah selesai (lulus) masih masuk dalam kajian manajemen kesiswaan. 


\section{Muhammad Miftah}

\section{Daftar Pustaka}

Arikunto, Suharsimi \& Lia Yuliana. Manajemen Pendidikan, Yogyakarta: Aditya Media, 2008.

Carolyn, M. Everton \& Edmund, T. Emmer, Manajemen Kelas untuk Guru Sekolah Dasar, Jakarta: Kencana, 2001.

Hasbullah, Malayu, Dasar-dasar Ilmu Pendidikan, Jakarta: Raja Grafindo Persada, 2005.

Herujito, Yayat M., Dasar-dasar Manajemen, Jakarta: Grasindo, 2001.

Mutohar, Prim Masrokhan, Manajemen Mutu Sekolah Strategi Peningkatan Mutu dan Daya Saing Lembaga Pendidikan Islam, Yogyakarta: Arruz Media, 2013.

Qomar, Mujamil, Manajemen Pendidikan Islam, Jakarta: Erlangga, 2007.

Rohiat. Manajemen Sekolah Teori Dasar dan Praktik, Bandung: Rafika Aditama, 2010.

Saleh, Rahman Abdul. Madrasah dan Pendidikan Anak Bangsa Visi Misi dan Aksi, Jakarta: Raja Grafindo Persada, 2001.

Soetopo, Hendayat, Pengantar Operasional Adminitrasi Pendidikan, Jakarta: Raja Grafindo, 2002.

Syafarudin, Manajemen Lembaga Pendidikan Islam, Jakarta: Ciputat Pres, 2005.

Tim Dosen Administrasi Pendidikan UPI, Manajemen Pendidikan, Bandung: Alfabeta, 2009.

Undang-undang RI No. 20 tahun 2003 tentang Sistem Pendidikan Nasional. 